\title{
Expense for Clinical Documentation of Inpatients: Extent and Hierarchal Differences for the Example of a Gynaecological Department in Switzerland
}

\author{
Ärztlicher Dokumentationsaufwand für stationäre Patienten: Ausmaß \\ und Hierarchieunterschiede am Beispiel einer Frauenklinik in der Schweiz
}

Authors

Affiliation
M. Thanner, G. Drack, R. Hornung

Frauenklinik, Kantonsspital St. Gallen, St. Gallen, Switzerland

\section{Key words \\ - documentation \\ - administration \\ - time study \\ - hospital \\ Schlüsselwörter \\ - Dokumentation \\ - Administration \\ - Arbeitszeitanalyse \\ - Krankenhaus}

Deutsche Version unter: www.thieme-connect.de/ ejournals/gebfra $\begin{array}{lr}\text { received } & 23.3 .2015 \\ \text { revised } & 11.8 .2015 \\ \text { accepted } & 17.9 .2015\end{array}$

Bibliography

DOI http://dx.doi.org/

10.1055/s-0035-1558273

Geburtsh Frauenheilk 2015; 75 :

1264-1269 ๑ Georg Thieme

Verlag KG Stuttgart · New York . ISSN 0016-5751

\section{Correspondence}

\section{Dr. rer. pol. Mirjam Thanner}

Kantonsspital St. Gallen

Frauenklinik

Rorschacher Strasse 95

9007 St. Gallen

Switzerland

mirjam.thanner@kssg.ch

\section{Abstract \\ $\nabla$}

Introduction: The majority of physicians consider administrative tasks to be a burden. The present questionnaire is intended to clarify the expense of time for documentation tasks in the treatment of inpatients in a gynaecological department of a Swiss hospital and to what extent differences occur between senior physicians and junior physicians.

Materials and Methods: For three weeks physicians in the gynaecological department of a central Swiss hospital documented minute for minute predefined tasks during their duty periods. A questionnaire in tabular form served as survey instrument for this working time analysis. The minute for minute details for the individual participants were summed for each clinical task listed in the questionnaire in order to subsequently calculate the amounts of time spent for the respective task categories and to subject them to a subgroup analysis.

Results: The participation rate of the physicians amounted to $87 \% .287$ questionnaires were included in the evaluation. According to the responses, $25 \%$ of the clinical working time for inpatients was used for documentation of clinical tasks. The subgroup analysis revealed a higher proportion for assistant physicians (30\%) than for senior physicians (18\%).

Discussion: The present working time analysis reveals an unfavourable ratio between surgical and administrative tasks between junior and senior physicians. In addition there is a danger that the true burden for junior physicians is underestimated by their superiors due to hierarchal differences.

\section{Zusammenfassung \\ $\nabla$}

Einleitung: Die Mehrheit der Ärzte nimmt administrative Tätigkeiten im Krankenhaus als Belastung wahr. Die vorliegende Befragung sollte klären, welchen Anteil Dokumentationsaufgaben bei der Behandlung stationärer Patienten einer Frauenklinik in der Schweiz einnehmen und in welchem Ausmaß dabei Unterschiede zwischen Ober- und Assistenzärzten auftreten.

Material und Methodik: Ärzte der Frauenklinik eines Zentrumspitals in der Schweiz dokumentierten 3 Wochen lang minutengenau vorab definierte Tätigkeiten während ihrer Schichten. Als Erhebungsinstrument der Arbeitszeitanalyse diente ein Fragebogen in Tabellenform. Die Minutenangaben der einzelnen Befragten wurden für jede der auf dem Fragebogen angegebenen ärztlichen Tätigkeiten addiert, um danach die Anteile der jeweiligen Tätigkeitskategorien zu berechnen und einer Subgruppenanalyse zu unterziehen.

Ergebnisse: Die Beteiligungsquote der Ärzte betrug 87\%. In die Auswertung gingen 287 Fragebögen ein. Den Angaben zufolge dienten 25\% der ärztlichen Arbeitszeit für stationäre Patienten der Dokumentation von klinischer Tätigkeit. Die Subgruppenanalyse ergab diesbez. für Assistenzärzte (30\%) einen höheren Anteil als für Oberärzte $(18 \%)$.

Diskussion: Die vorliegende Arbeitszeitanalyse zeigt ein ungünstiges Verhältnis von operativen und administrativen Tätigkeiten für Assistenzund Oberärzte. Zudem besteht die Gefahr, dass aufgrund von Hierarchieunterschieden die wahre Belastung der Assistenzärzte durch deren Vorgesetzte unterschätzt wird. 


\section{Introduction}

\section{$\nabla$}

The majority of physicians in hospitals consider administrative tasks rather to be a burden [1-2]. Furthermore, it is feared that especially young physicians are becoming increasingly involved in these tasks [3] and thus may seek other professional fields. This is especially true for the younger generation of physicians in surgical specialties, since a defined catalogue of operations has to be completed to gain a further training title. Tasks outside of the operating theatre without direct patient contacts are often considered to be particularly unattractive [4]. The medical directors of the hospital are thus faced with the challenge of maintaining patient management at a high level and at the same time of keeping an eye on the professional progress of the junior physicians. If the different hierarchal levels in the hospital have to spend varying amounts of time on documentation tasks this can in the absence of a data base and transparency lead to the real burden for the junior physicians being systematically underestimated by their superiors.

Even though an excess of documentation responsibilities may be considered as a burden, documentation tasks do indeed play important roles in the clinical routine, e.g., as memory aids or communication instruments. In addition, they serve as the foundation for reimbursements for performed services and as evidence for liability issues [2].

In the literature there are indications that the time expenditure for documentation has increased in the course of time [5]. Although working time analyses are also becoming more important in hospitals [6], a lack of studies from the 1980s or 1990s, which would be necessary for direct comparisons, has been reported [7]. The reasons mentioned in the literature for the increases in administrative tasks, on the other hand, are manifold. On the one hand, there are increasing demands for information from the patients and from the funding agencies: patients and health insurances more frequently ask for information about the services performed by the physician, whether or not he/she is working economically and if the treatments are successful $[2,5]$. The increase in administrative expenditure could also represent the result of the higher need for coordination among the participating physicians in complicated cases [8]. Increasing specialisation, legal limitations of working time as well as more part-time employment increase the interfaces at which information can be lost when there is inadequate documentation. Since balancing career and family also includes the possibility to at least temporarily work part time, the coordination of part-time employment is of increasing importance in the daily routine of medical directors, especially in the light of the large proportion of female medical graduates [9-10].

Even when many different professional groups are involved in documentation tasks, the main burden of these tasks still seems to be carried by the physicians [11]. Studies analysing the working time of physicians, however, allow one to assume large differences in the percent proportion of documentation expenditure [12]. Besides the specialty, the scattering can also be due to, e.g., differences in the division of work in the respective hospital [1314] or to varying survey methodologies [15]. In the literature there is especially a lack of working time analyses for the nonuniversity setting [12]. It can thus be assumed that physicians spend 10 to $40 \%$ of their working time for administrative tasks [12-13,16-18]. The relationship between patient near and patient distant tasks is considered to be especially problematic by junior physicians [14].
Against this background, the present study is intended to clarify in a non-university hospital with central functions just how much time physicians spend on medical documentation tasks in the treatment of inpatients and to what extent differences can be determined between the levels of medical hierarchy.

\section{Materials and Methods \\ $\nabla$}

Organisation of the studied gynaecology department

The studied gynaecology department is divided into five specialties - gynaecology and gynaecological oncology, uro-gynaecology, foeto-maternal medicine and obstetrics, endocrinology and reproduction medicine as well as neonatology. Each year over 2500 gynaecological interventions are performed in the department (including major tumour surgery with an emphasis on endoscopic procedures) and over 1400 births are managed - with a large proportion of high-risk pregnancies. The department in question is certified for advanced medical education in the specialties surgical gynaecology and obstetrics, foeto-maternal medicine, gynaecological oncology as well as reproduction medicine and gynaecological endocrinology. During the study period, seven consultants (head physicians, leading physicians, senior physicians with special functions), eight senior physicians, one hospital specialist and 14 residents were working in the department. With the exception of one head physician in the specialty neonatology, all other physicians in the gynaecology department possessed or were in the process of obtaining a continuing education title for the specialty gynaecology and obstetrics. The local children's hospital was responsible for provision of the senior and junior physicians for neonatology. By means of a three-shift system the gynaecology department was able to maintain a presence service of at least one junior physician and at least one senior physician in the specialty gynaecology and obstetrics during 24 hours for seven days per week. In addition, outside of office hours at least one head physician was on call as a so-called background service.

\section{Random sample and survey instrument}

In September 2012, all physicians involved in patient care in the studied gynaecological department were asked to document previously defined tasks minute-by-minute for three weeks. The paediatric senior and junior physicians from the local children's hospital who provided the neonatology services in the department were not included in the study. The physicians of the breast centre, as an independent organisational unit, were also not enrolled in the survey.

A questionnaire in tabular form was used as the survey instrument. It included various categories of activities that need to be undertaken when the physician is physically present in the gynaecology department. The subdivision of the medical tasks was proposed by two of the authors, evaluated in two internal hospital meetings (participants: members of the hospital direction from the medical, nursing and administration fields, senior physicians, and representative junior physicians) and subjected to a pre-test by one junior and one senior physician. Activities for inpatients that were relevant for the study were finally included in the questionnaire:

- work involving the inpatients, including reports, tumour board, perinatal board and reviewing records

- work involving documentation of clinical tasks for the inpatients 
Table 1 Example for the calculations (according to the time reports in a questionnaire completed by a senior physician).

\begin{tabular}{|c|c|c|c|c|c|c|}
\hline & & Type of task (min) & Morning & Afternoon & Sum & $\begin{array}{l}\text { Calculation: proportion } \\
\text { of total working time }\end{array}$ \\
\hline \multirow[t]{5}{*}{ Female inpatient } & $\begin{array}{l}\text { work on } \\
\text { the ward }\end{array}$ & $\begin{array}{l}\text { work at the patient (incl. report, tumour } \\
\text { board, perinatal board, preparation, } \\
\text { e.g., consulting records) }\end{array}$ & 80 & 75 & 155 & $24 \%$ \\
\hline & & work for documenting clinical tasks & & 30 & 30 & $5 \%$ \\
\hline & & $\begin{array}{l}\text { conversation with relatives } \\
\text { (without the patient) }\end{array}$ & & & & \\
\hline & & counselling & & 30 & 30 & $5 \%$ \\
\hline & OPS & OPS tasks for inpatients & 120 & 60 & 180 & $28 \%$ \\
\hline \multirow[t]{2}{*}{ Female outpatient } & OPS & OPS tasks for outpatients & & & & \\
\hline & AMB & outpatient tasks (without operations) & 120 & 60 & 180 & $28 \%$ \\
\hline$T \& R$ & & teaching and research tasks & & & & \\
\hline$F \& E$ & & own further training and education & 10 & 60 & 70 & $11 \%$ \\
\hline \multirow[t]{2}{*}{ etc. } & & $\begin{array}{l}\text { meetings (e.g. clinical conferences, } \\
\text { quality management) or similar }\end{array}$ & & & & \\
\hline & & total working time ( $\mathrm{min}$ ) & 330 & 315 & 645 & $100 \%$ \\
\hline
\end{tabular}

- conversations with the relatives of the inpatients

- consultations with the inpatients

- surgical activities for the inpatients

At the end of August 2012, the survey instrument was presented to the participating physicians during a department conference; the physicians were especially given an opportunity to ask questions about the assignments of specific tasks to the defined categories. At the time of the study the department already possessed an electronic patient management system so that, for example, the entire medical reporting system such as writing or dictating a doctor's letter could be assigned to the category "work for documenting clinical tasks on the inpatient".

Two types of questionnaire were used: one served to record tasks during the day (divided into the time periods morning and afternoon) and could be used by the physicians assigned to early or late shift duty, the other was not divided into time periods and was used by the night shift. Apart from the time divisions, the questionnaires for day-time and night-time did not differ with regard to task categories. The physicians in the early shift were asked to complete the section "morning" at the latest before the lunch break and the section "afternoon" at the latest before leaving the hospital. The physicians in the late shift could ignore the section "morning", physicians in the night shift were expected to complete the questionnaire at the latest after completion of their duty the next morning. The time subdivision was considered to be an aid for completion of the form; in the evaluation merely the sum of the minutes for the individual tasks during a shift were used. A differentiation with regard to weekdays, weekends or public holidays was not made.

\section{Data evaluation}

The minute for minute records for the individual participants were summed for each and every medical task mentioned in the questionnaire and then the proportions calculated for the respective task categories. For the subgroup analyses the Mann-Whitney $U$ test was used to compare two independent samples. The Kolmogorov-Smirnov test was used to assess the type of distribution. Statistical analyses were carried out with the help of the programme packet SPSS 20. Table 1 exemplarily shows the calculations for a questionnaire completed by a senior physician.
Table 2 Physicians participating in the survey.

\begin{tabular}{|l|ccl|}
\hline Physician group & $\begin{array}{l}\text { Target } \\
\text { number }\end{array}$ & $\begin{array}{l}\text { Actual } \\
\text { number }\end{array}$ & $\begin{array}{l}\text { Participation } \\
\text { rate }\end{array}$ \\
\hline Consultants & 7 & 5 & \\
\hline Senior physicians & 8 & 7 & \\
\hline Hospital consultants & 1 & 1 & \\
\hline Junior physicians & 14 & 13 & $\mathbf{8 7 \%}$ \\
\hline Total & $\mathbf{3 0}$ & $\mathbf{2 6}$ & \\
\hline
\end{tabular}

\section{Results \\ $\nabla$}

\section{Description of the sample}

$87 \%$ of the physicians employed in the gynaecological department and actively involved in patient care participated in the survey (for details, see $\bigcirc$ Table 2). 287 questionnaires were included in the evaluation. The answers of the only hospital consultant (Spitalfacharzt) employed in the gynaecological department were not included in the evaluation for the sake of anonymity. According to the definition, times within the assessment period in which the physicians were not physically present in the department, e.g., sick leave, holidays, compensation days or time working at home, were not included in the evaluation. Also further training and education times as well as research or teaching tasks were not recorded when these occurred exclusively outside of the gynaecological department. This is important because the results of the survey cannot be directly transferred to the physician's contractual working time. The sample included 248 questionnaires from the early and late shifts as well as 39 from the night shift (for details, see 0 Table 3). Altogether, 163205 minutes working time in the gynaecological department were assessed. On average one questionnaire described the work contents of 569 minutes (average 569, median 580, min. 110, max. 1060).

\section{Structure of the evaluated working time - total}

According to the assessment, on average $61 \%$ of the evaluated working time was used for inpatients, $30 \%$ for outpatients and $9 \%$ for internal teaching and research work, further training and education as well as various meetings, e.g., clinic conferences (CliCo) or meetings of the working group quality management 
Table 3 Number of questionnaires included in the evaluation according to physician group and duty shift.

\begin{tabular}{|c|c|c|c|}
\hline Physician group & Number of questionnaires from early and late shifts & Number of questionnaires from night shift & Total \\
\hline Consultants & 63 & 7 & 70 \\
\hline Senior physicians & 55 & 13 & 68 \\
\hline Junior physicians & 130 & 19 & 149 \\
\hline Total & 248 & 39 & 287 \\
\hline
\end{tabular}

Table 4 Proportions of the recorded working time in percent for the individual working contents arranged according to physician groups.

\begin{tabular}{|c|c|c|c|c|c|c|}
\hline & & & $\begin{array}{l}\text { Consultants } \\
\text { ( } n=70 \text { ques- } \\
\text { tionnaires) }\end{array}$ & $\begin{array}{l}\text { Senior physicians } \\
\text { ( } n=68 \\
\text { questionnaires) }\end{array}$ & $\begin{array}{l}\text { Junior physicians } \\
\text { ( } n=149 \\
\text { questionnaires) }\end{array}$ & $\begin{array}{l}\text { Total } \\
\text { ( } \mathrm{n}=\mathbf{2 8 7} \text { ques- } \\
\text { tionnaires) }\end{array}$ \\
\hline \multirow[t]{5}{*}{$\begin{array}{l}\text { Female } \\
\text { inpatient }\end{array}$} & $\begin{array}{l}\text { work on } \\
\text { the ward }\end{array}$ & $\begin{array}{l}\text { work on patient (including report, tumour } \\
\text { board, perinatal board, preparation, } \\
\text { e.g. consulting records) }\end{array}$ & $32 \%$ & $27 \%$ & $33 \%$ & $31 \%$ \\
\hline & & work on documentation of clinical tasks & $12 \%$ & $12 \%$ & $18 \%$ & $15 \%$ \\
\hline & & $\begin{array}{l}\text { conversations with relatives } \\
\text { (without the patient) }\end{array}$ & $3 \%$ & $2 \%$ & $0 \%$ & $2 \%$ \\
\hline & & counselling & $1 \%$ & $4 \%$ & $1 \%$ & $1 \%$ \\
\hline & OPS & OPS tasks for inpatients & $10 \%$ & $22 \%$ & $8 \%$ & $12 \%$ \\
\hline \multirow{2}{*}{$\begin{array}{l}\text { Female } \\
\text { outpatient }\end{array}$} & OPS & OPS tasks for outpatients & $0 \%$ & $3 \%$ & $4 \%$ & $3 \%$ \\
\hline & AMB & outpatient task (other than operations) & $20 \%$ & $22 \%$ & $32 \%$ & $27 \%$ \\
\hline$T \& R$ & & teaching and research tasks & $5 \%$ & $2 \%$ & $1 \%$ & $2 \%$ \\
\hline$F \& E$ & & own further training and education & $3 \%$ & $5 \%$ & $3 \%$ & $3 \%$ \\
\hline Etc. & & meetings (e.g., CliCo, QM) or similar & $15 \%$ & $1 \%$ & $0 \%$ & $4 \%$ \\
\hline
\end{tabular}

Table 5 Proportions of the recorded working time in percent for the individual working contents for inpatients arranged according to duty shift.

\begin{tabular}{|c|c|c|c|c|c|}
\hline & & & $\begin{array}{l}\text { Early and late shifts } \\
\text { ( } \mathrm{n}=\mathbf{2 4 8} \text { questionnaires) }\end{array}$ & $\begin{array}{l}\text { Night shift ( } n=39 \\
\text { questionnaires) }\end{array}$ & $\begin{array}{l}\text { Total ( } n=287 \\
\text { questionnaires) }\end{array}$ \\
\hline \multirow[t]{5}{*}{$\begin{array}{l}\text { Female } \\
\text { inpatient }\end{array}$} & $\begin{array}{l}\text { work on } \\
\text { the ward }\end{array}$ & $\begin{array}{l}\text { work on patient (including report, tumour board, } \\
\text { perinatal board, preparation, e.g. consulting records) }\end{array}$ & $49 \%$ & $59 \%$ & $51 \%$ \\
\hline & & work on documentation of clinical tasks & $25 \%$ & $21 \%$ & $25 \%$ \\
\hline & & conversations with relatives (without the patient) & $3 \%$ & $2 \%$ & $3 \%$ \\
\hline & & counselling & $2 \%$ & $3 \%$ & $2 \%$ \\
\hline & OPS & OPS tasks for inpatients & $21 \%$ & $15 \%$ & $19 \%$ \\
\hline
\end{tabular}

Table 6 Proportions of the recorded working time in percent for the individual working contents for inpatients arranged according to physician groups.

\begin{tabular}{|c|c|c|c|c|c|c|}
\hline & & & $\begin{array}{l}\text { Consultants } \\
\text { ( } n=70 \text { ques- } \\
\text { tionnaires) }\end{array}$ & $\begin{array}{l}\text { Senior physicians } \\
\text { ( } n=68 \text { question- } \\
\text { naires) }\end{array}$ & $\begin{array}{l}\text { Junior physicians } \\
\text { ( } n=149 \text { question- } \\
\text { naires) }\end{array}$ & $\begin{array}{l}\text { Total } \\
\text { ( } \mathrm{n}=\mathbf{2 8 7} \text { ques- } \\
\text { tionnaires) }\end{array}$ \\
\hline \multirow[t]{5}{*}{$\begin{array}{l}\text { Female } \\
\text { inpatient }\end{array}$} & $\begin{array}{l}\text { work on } \\
\text { the ward }\end{array}$ & $\begin{array}{l}\text { work on patient (including report, tumour } \\
\text { board, perinatal board, preparation, } \\
\text { e.g. consulting records) }\end{array}$ & $56 \%$ & $40 \%$ & $54 \%$ & $51 \%$ \\
\hline & & work on documentation of clinical tasks & $20 \%$ & $18 \%$ & $30 \%$ & $25 \%$ \\
\hline & & $\begin{array}{l}\text { conversations with relatives (without the } \\
\text { patient) }\end{array}$ & $6 \%$ & $3 \%$ & $1 \%$ & $3 \%$ \\
\hline & & counselling & $1 \%$ & $6 \%$ & $1 \%$ & $2 \%$ \\
\hline & OPS & OPS tasks for inpatients & $17 \%$ & $33 \%$ & $13 \%$ & $19 \%$ \\
\hline
\end{tabular}

(QM). Table 4 shows the detailed results for the individual physician groups.

Structure of the evaluated working time - inpatients If we consider only the recorded working time for inpatients it is seen that $51 \%$ is taken up with tasks near to the patient on the ward and $25 \%$ for work on the documentation of clinical tasks; $19 \%$ was used for surgical tasks, $3 \%$ for conversations with the relatives of inpatients and $2 \%$ for counselling tasks. Table 5 lists the structure of daytime differences in recorded working times for inpatients in the early and late shifts in comparison to the night shift; $\bigcirc$ Table 6 shows the averaged results for the individual physician groups.

The subgroup analysis ( $\bullet$ Fig. 1 ) revealed that junior physicians spend $30 \%$ of their working time for inpatients to complete documentation tasks. For senior physicians this takes up $18 \%$ Whereas senior physicians spend 33\% of their working time for inpatients on surgical tasks these take up only $13 \%$ of the working time of junior physicians. The differences for each time are highly significant ( $\mathrm{p}=0.001$; Mann-Whitney U test). 


\section{Discussion}

Physicians in the investigated setting spend on average one quarter of their working time for inpatients on documentation tasks. The results of other working time studies are not well comparable with one another or with the survey described here. This is due, on the one hand, to differing samples and survey methods (e.g., self-estimations vs. third party observations) [19] and, on the other hand, that different task categories were used in each of the surveys. Since the present study was carried out within the framework of the introduction of Swiss DRG (diagnosis-related groups) and not only reimbursement modalities but also the processes of patient management in the outpatient and inpatient sectors differed, the focus was placed on inpatients for the comparison of the proportion of working time that junior and senior physicians spent on documentation tasks and on surgical tasks. In general it is assumed in the international literature that physicians spend 10 to $40 \%$ of their total working time on documentation tasks $[12-14,16-18,20]$. The present results are thus not surprising against this background.

In the present study for junior physicians in particular an unfavourable ratio between documentation and operating time was seen. This carries the danger of dissatisfaction among physicians in continuing medical education. Even now it is suspected in Germany that an improvement in recruitment of the next generation of surgeons will not result from merely an increase in the basic salary but will also require a safeguarding of the OP catalogue or a reduction of time spent on medical documentation [4]. In regard to this conclusion, the present survey is in agreement with a Switzerland-wide survey of hospital physicians of all disciplines held in 2011 [14]. It is worth mentioning that in the mentioned study the relationship between patient-near and patient-distant tasks for junior physicians was classified as problematic even before the country-wide introduction of the Swiss DRG system in 2012. This finding may help to prevent the Swiss DRG from too easily becoming "a symbol for the sense of grievance in daily medical routine" [14]. Also in the framework of a German study on the effects of DRG on management quality and working conditions in hospitals, there was a warning about "the idolisation of pre-fees per case times in which already journalistic or even stereotype comments about too much administrative work can be found" [7].

The present study demonstrates the extent and the hierarchal differences in time expenditure for medical documentation in a non-university Swiss central hospital. In comparison to the available literature, this study takes possible specialty (gynaecology and obstetrics) and regional characteristics more strongly into consideration and at the same time widens the perspectives of described research results since the previously available studies concentrated principally on the university setting [12]. In addition, this survey showed that working time analyses not only can be applied in the framework of hospital cost calculations and process optimisation but also provide support in the field of personnel management [6].

A major limitation of the study is that it only allows conclusions to be made in cross-section for the given case examples. It does not allow conclusions to be drawn about the time expenditure for documentation in other gynaecological departments. Also no reliable information can be deduced about how the contents and composition of medical tasks have changed over time. Although the authors had access to the results of a similar survey in the clinic in question from the middle of the 1980s - at that time

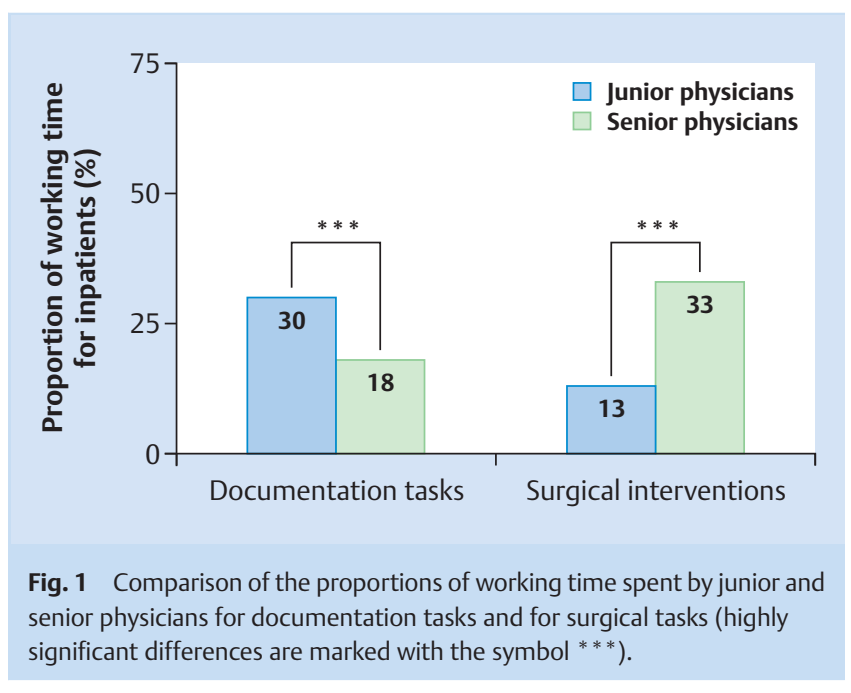

merely $10 \%$ of the working time of junior physicians was taken up by administrative work - the differing objectives and different categories of the survey tasks prevent a direct comparison, even when this would have been highly desirable. An additional limitation is that the present analysis is based on self-estimations of the participating physicians. On the one hand these are considered to be rather inaccurate since, for example, in the case of an insufficient selectivity between the individual task categories this opens up a wide-ranging latitude for subjective assessments. On the other hand, it can be carried out relatively quickly and cheaply. Furthermore it can be considered advantageous that the participants view the procedure less as a control of their own work and thus do not oppose the survey from the very beginning [6]. However, it could be possible that the time expended for those tasks that are felt to be unpleasant such as, for example, documentation are unconsciously or deliberately overestimated [21-22]. It has already been suggested for other analyses of medical tasks that the opinion of the respective participant could have had an influence of the study situation [23]. For similar investigations in the future it would be reasonable to compare the individual results with statistics available from the hospital's own clinical information system, e.g., electronic operation management system.

A high time expenditure for documentation represents a risk to the job satisfaction of the young physicians. In addition, there is the danger that, on account of the described differences between the hierarchal stages, the real burden for the junior physicians is underestimated by their superiors. Irrespective of the assumed efficiency reserves [12-13,24], a high time expenditure for documentation tasks harbours additional potential for conflict within the medical team. As studies have shown that the intensity of the perceived burden of documentation tasks also depends on the amount of support that the physicians receive for carrying out these tasks from their organisations [1], working time analysis seems to be a useful instrument to create awareness and transparency with regard to the distribution of documentation work within the medical team. The results could provide a basis for discussions as to where relief is reasonable, so that more important training targets can be achieved more rapidly and that continuing medical training can become more attractive for young physicians. 
Whether or not a proportion of $25 \%$ of the medical working time with inpatients for documentation tasks is considered to be too high or appropriate is certainly a topic for controversial discussion. There is usually consensus that "unnecessary administrative work" should be avoided - however, more difficult is the decision as to what is in fact unnecessary since here there are perception differences depending on individual perspectives.

With regard to efficiency questions, it must be considered that a lower expenditure in one position usually means a larger expenditure somewhere else $[21,25]$. If, in this context, complaints are made about the lack of use of information technology, it is advisable to consider not only the use but also the cost of alternatives. The medical employees have to balance the material and personnel resources of the IT sector that are needed to implement and maintain redundancy-free documentation. In the literature one often finds the demand to use medical capacities "more diligently and better targeted": instead of in the core business, the treatment of patients, personnel resources are tied up in administration. Thus, in most hospitals the physicians carry out numerous administrative tasks such as administration of examinations, obtaining cost approvals, writing certificates, dictating or writing reports, coding, recording services, transmission of regulations, issuing prescriptions and medical certificates, filling out forms and running errands [24]. In essence, this is the background for the criticism that many administrative tasks are assigned to the expensive medical personnel which could be equally well undertaken by other professional groups with lower personnel costs [26]. However, we should not lose sight of the fact that also general secretary, special documentation or so-called clinical assistant positions $[11,27]$ are not free of costs and must be applied for and financed. Otherwise, the initial delight about additionally approved physician positions can easily be marred by the annoyance of an administrative overload. Viable solutions thus require first of all a fundamental philosophy that the future of hospitals "definitely does not lay only in the increase of medical knowledge but also in the further development of interactional and social factors" [28].

\section{Practical Conclusions}

The present working time analysis revealed an unfavourable relationship of surgical and administrative tasks between junior and senior physicians. This harbours the risk of dissatisfaction among the junior physicians. In addition there is the danger that, due to the described differences between the hierarchal stages, the real burden for the junior physicians is underestimated by their superiors. Irrespective of the assumed efficiency reserves, a high time expenditure for documentation harbours an additional potential for conflict within the medical team.

\section{Conflict of Interest}

\section{$\nabla$}

None.

\section{References}

1 Gothe H, Köster AD, Storz P et al. Arbeits- und Berufszufriedenheit von Ärzten. Eine Übersicht der internationalen Literatur. Deutsches Ärzteblatt 2007; 104: A1394-A1399

2 Staufer F, Staufer A. Verwaltungsarbeit in Klinik und Praxis. Bürokratische Belastung. Der Gynäkologe 2011; 44: 368-374
3 Hoppe JD (zitiert nach Weber R). 113. Deutscher Ärztetag. Stenografischer Wortbericht. Dresden: Bundesärztekammer; 2010: 47

4 Mroczkowski P, Granowski D, Nestler G et al. Situation des chirurgischen Nachwuchses in Mitteldeutschland. Der Chirurg 2007; 78: 254-258

5 Beckmann K, Jud S, Hein A et al. Dokumentation in der gynäkologischen Onkologie. Gynäkologe 2010; 43: 400-410

6 Fehrle M, Michl S, Alte D et al. Zeitmessstudien im Krankenhaus. Gesundheitsökonomie und Qualitätsmanagement 2013; 18: 23-30

7 Braun B, Buhr P, Klinike S et al. Pauschalpatienten, Kurzlieger und Draufzahler - Auswirkungen der DRGs auf Versorgungsqualität und Arbeitsbedingungen im Krankenhaus. Bern: Hans Huber; 2010

8 Rüegg-Stürm J, Tuckermann H. Warum immer mehr „Administration“? Wege aus der „Administrationsfalle“. Schweiz Ärzteztg 2008; 89: 271275

9 Biedenkopf A. Die Entscheidung nach dem PJ: Chirurgie - ja oder nein? Dtsch Med Wochenschr 2004; 129: 963-966

10 Hancke $K$, Toth B, Igl W et al. Career and family - are they compatible? Results of a survey of male and female gynaecologists in Germany. Geburtsh Frauenheilk 2012; 72: 403-407

11 Lux MP, Sell CS, Fasching PA et al. Time and resources needed to document patients with breast cancer from primary diagnosis to follow-up - results of a single-center study. Geburtsh Frauenheilk 2014; 74: 743751

12 Tipping MD, Forth VE, Magill DB et al. Systematic review of time studies evaluating physicians in the hospital setting. J Hosp Med 2010; 5: 353 359

13 Blum K, Müller U. Dokumentationsaufwand im Ärztlichen Dienst der Krankenhäuser. Repräsentativerhebung des Deutschen Krankenhausinstituts. Das Krankenhaus 2003; 95: 544-548

14 Golder L, Longchamp C, Imfeld M et al. DRG: Befürchtungen einer zunehmenden Bürokratisierung der Medizin. Bern: gfs.bern; 2011

15 Ampt A, Westbrook J, Creswick $N$ et al. A comparison of self-reported and observational work sampling techniques for measuring time in nursing tasks. J Health Serv Res Policy 2007; 12: 18-24

16 Scheel O, Thiry E, Schmidt-Rhode C et al. Deutsches Gesundheitssystem auf dem Prüfstand. Kostenfalle Komplexität. Eine Studie von A. T. Kearney. Düsseldorf: A. T. Kearney; 2011

17 Ammenwerth E, Spötl HP. The time needed for clinical documentation versus direct patient care. A work-sampling analysis of physicians' acitivities. Methods Inf Med 2009; 48: 84-91

18 Cerwenka H, Bacher H, Werkgartner $G$ et al. Working conditions and trainee shortage in operative disciplines - is our profession ready for the next decade? Arch Surg 2009; 394: 179-183

19 Finkler SA, Knickman JR, Hendrickson $G$ et al. A comparison of worksampling and time-and-motion techniques for studies in health services research. Health Serv Res 1993; 28: 577-597

20 Schuld J, Bobkowski M, Shayesteh-Kheslat R et al. Ärztliche Ressourcennutzung in der Chirurgie auf dem Prüfstand - eine WorksamplingAnalyse an einer deutschen Universitätsklinik. Zentralblatt für Chirurgie 2013; 138: 151-156

21 Becker G, Kempf DE, Xander CJ et al. Four minutes for a patient, twenty seconds for a relative - an observational study at a university hospital. BMC Health Services Research 2010. Online: http://www.biomedcentral.com/1472-6963/10/94; last access: 30.11 .2015

22 Burke TA, McKee JR, Wilson HC et al. A comparison of time-and-motion and self-reporting methods of work measurement. J Nurs Adm 2000; 30: $118-125$

23 Mache S, Kelm R, Bauer H et al. General and visceral surgery practice in German hospitals: a real-time work analysis on surgeons' work flow. Langenbecks Arch Surg 2010; 395: 81-87

24 Schnyder $A B$. Manifest „Medizin gegen Spital-Bürokratie“. Schweiz Ärzteztg 2012; 93: 107-108

25 Mitchell J, Hayhurst C, Robinson SM. Can a senior house officer's time be used more effectively? Emerg Med J 2004; 21: 545-547

26 Stark S, Hölzer S. Dokumentations- und Kodierprozesse im Spital: Herausforderungen und Massnahmen. Schweiz Ärzteztg 2005; 86: $1944-$ 1946

27 Kaiser R, Stüwe U, Happel S. „Klinikassistenz“ zur administrativ-organisatorischen Unterstützung von Krankenhausärzten. Anaesthesist 2005; 54: 57-60

28 von Arx W, Rüegg-Stürm J. Spitäler im Umbruch - Ansatzpunkte für eine gelingende Weiterentwicklung. Schweiz Ärzteztg 2007; 88: $1214-1219$ 